\title{
A TEACHER'S AUTONOMY IN ASSESSING STUDENTS' PERFORMANCE: A BRIEF CONCEPTUAL REVIEW ON THE ASSESSMENT OF LEARNING OUTCOMES
}

\author{
Wamaungo Juma Abdu \\ $a^{*}$ Department of Adult and Community Education, Faculty of Special Needs and Rehabilitation, Kyambogo \\ University \\ Kyambogo University, P.O. Box 1, Kampala, Uganda \\ jwamaungo@kyu.ac.ug
}

\begin{abstract}
In formal schooling, testing/ or assessments are always done on entry, and on exit of the student. Assessment during entry is carried out to assess the entry behaviour of a student, while the on-exit assessment is conducted to know how well students have achieved on the learning objectives. This means that assessment of a student has always had a strong foundation in the 'hands of the teacher'. Having taught, a teacher understands the students than any other assessor or evaluator. However, this is not the case in most countries, more so in the developing world, where students' testing/assessment has always been done by the national examination bodies, a thing which terminates the teacher's role in student's assessment, hence hindering sincere evaluation of learners. Mr. Obama describes such a situation as teachers forced to spend their academic years preparing students to fill in bubbles on standardized tests (Cody, 2011). This Obama comment implies that teachers should be given authority in a substantive manner towards a more balanced method for evaluating students learning and achievement. In this paper therefore, I describe the need for a teacher's autonomy in testing and or assessing students' performance [school assessment] versus the national examinations organized by the national examination body under the ministry of education..
\end{abstract}

Keywords: Autonomy, assessment, learning outcomes, testing and teacher autonomy.

\section{INTRODUCTION}

Education is vital for personal, social, and economic development (Wamaungo, 2014; Osmankovic, Jahic and Sehic, 2011). There is no country that has developed, without substantial investment in human (Ozturk, 2001) growth and development. Poor education largely and badly impacts on national development (Hanushek and Wößmann, 2007). Upon, most governments consider education as a national interest, that facilitates sustainable growth and development of a country. Hence, the dream for every nation to implement a wellplanned national education system, which benefits each, and every citizen. Because the progress of any economy and country's education success inextricably depends on each other (The White House, 2016), all the education efforts aim at achieving the learning objectives set prior to learning. A teacher's autonomy and academic freedom is an important aspect (Sehrawat, 2014) which makes highly significant substructures that are integral to the idea of students assessment.

In an autonomous environment the teacher is responsible during the teaching and learning processes. Is the education manager, seen as a controlling figure of educational process and play critical role in the power of social change (Sehrawat, 2014). Teachers and of course schools are always regarded as two ideas which are unavoidable and of value to society and where there is advocacy for more so schools, there is also advocacy for more teachers. It is 


\section{Wamaungo Juma Abdu. /Journal of Educational Administration Research and Review / Vol.3 No.1 June 2019}

due to the importance of a teacher that developed countries are providing all the necessary resources to keep a teacher in school. Countries such as the USA provides funding to make sure it keeps hundreds of thousands of teachers on the such that they prevent layoffs of any teacher (The White House, 2016).

\section{METHODS}

The approach used in this research is qualitative descriptive research method, which aims to describe the current condition of field research or when the research is conducted. The data collected is in the form of qualitative to get the meaning of the observed phenomenon. Data collection is done through natural settings, and laboratory experimental methods, data and information that have been obtained by researchers, analyzed and interpreted from the beginning of the study to the end of the study by referring to the theoretical basis relating to the problem under study. Data analysis is done by classifying, directing, deleting unnecessary, and reducing data, display, and verification of withdrawals.

\section{RESULTS AND DISCUSSION}

\section{A. Results}

The Teacher-Educator Autonomy in Students Testing and Assessment

Autonomy protects the corporate rights of selfregulation (Price and Verhulst, 2000), which the state confers upon the schools as institutions for knowledge creation and innovation by law (Harker, 1911). Teachers/ or educators are expected to be more closely engaged in decision making on the educational matters, more so in the assessment of their students or/ learners, since they are the sole trainers or instructors in the day to day process of education in both the nonformal sector and the formal schooling.

The preparation of syllabuses, teaching materials and of course examination materials should be carried out with the participation of practicing teachers, since evaluation of learning outcomes cannot be dissociated from the way that teachers teach (NCTE, 2009). Similarly, the system of school management, school inspection and teacher evaluation and assessment (OECD, 2013; Sequera, 2018) can only stand to gain from including teachers in the assessment and evaluation processes.

Autonomy can therefore be described as the leading and control of both the teaching and learning processes, including the assessment and evaluation of students learning objectives. In the formal schooling, traditionally the role of the teacher has been as a purveyor of information and the fount of knowledge (Reece and Walker, 2000). This suggested a situation whereby students sit in rows in front of the teacher that is talking and passing information to students with the aid of blackboards (Brown, 2018), while the students either listen passively or, if the teacher is lucky, take their own notes. This is the same story to the national examination board where by the teacher's role has been grabbed by the team of observers who claim to be experts in examining, a thing which brings incompetency in teachers (Ali and Rizvi, 2007) since they feel their role is to only fill empty students with knowledge who are at the end determined by a pen of examination experts.

\section{The Teacher-Educator as a Facilitator}

Teachers of formal schooling differ from those of the nonformal education sector, because in nonformal education, students are not considered to be empty in mind but come to learning sessions with prior experiences. With modernity and at a time the younger are continuously becoming digital natives, a modern teacher is a facilitator: a person who assists students to learn for themselves. Instead of having students sit in rows, they are likely to be in groups, all doing something different; some doing practical tasks, some writing (William and Ochan, 2011), some not even in the room, but in another part of the building using specialist equipment or looking up something in the library. The students might well be at different stages in their learning and in consequence, the learning is individualized 
to suit individual requirements and abilities (Reece and Walker, 2000).

\section{B. Discussion}

Based on the result, it is then clear that for students; testing, grading, assessment and evaluation should be a sole responsibility of the teachers (Rand Education Research Brief, 2004), because national examinations are only set at a distance without taking in consideration the changes in learning and teaching and above all not considering the geographical location, activities and other common features of a given area and time.

Thus, in this paper, I look at how best the teacher's autonomy in assessing students learning (OECD/CERI, 2008), might best serve the interest of the country without spoiling the country's education standards verses the polemic national exams.

\section{Autonomy}

Can be described as the capacity to take the responsibility for, or control over your own activities (Sehrawat, 2014). Advanced learners' dictionary defines autonomy as "the ability to make your own decisions about what to do rather than being influenced by someone else or told what to do" (Sinclair, 1995). Autonomous testing and assessment offer teachers the freedom and opportunity to make decisions about the content, organisation and pace of their student evaluation (Strong, 2012). Giving autonomy to schools to determine the final performance of students seems to be a rational solution to the chaos of failure of students in national examination.

The teacher or tutor is fully autonomous when he is working individually or in a group, taking responsibility for the planning, monitoring and evaluation of his students (OECD, 2009); the teacher cannot, of course, be fully autonomous within the framework of a nationwide curriculum (Eurydice, 2008), but the more responsibility he is given in any of the three areas of planning, monitoring and evaluation, the more autonomous he becomes.
Based on the above, autonomy can be analyzed in terms of knowledge, skills and attitudes. Littlewood (1996) mentions that ability can be divided into knowledge and skills. Knowledge may include an awareness of alternatives that might be chosen, and the skill to implement any choices made. The attitudinal component of autonomy is discussed by Littlewood under the heading of willingness (1996). Littlewood (1996) further points out that "it is not enough to know how to do something. There must also be the motivation and confidence to do something".

While discussing learners Little (2007a) describes how some aspects of autonomy could be recognised in behaviour. Besides decision making, he adds there should be a capacity for detachment, critical reflection and independent action. These would also be features of an autonomous teacher. Autonomy is not the same as independent work and teachers may share autonomy in joint work (Little, 1990b).

Teachers' Autonomy

Teacher autonomy is a situation where under the supervision of the ministry of education, schools can determine, separately from that authority, specific functions entrusted upon them, by the Ministry, for the general welfare of the students to whom the school is responsible. This boost honest among students. McClain, Gulbis and Hays (2017) are of the view that when students trust the evaluation process and believe that it effectively measures their competences, they then become honest. This implies that, giving schools and teachers the autonomy, they deserve to handle issues related to school management, evaluation and assessment of their learners, obviously contributes a trusted education system which is also democratic and encourages morality within national development. Therefore, empowering teachers is key to good pedagogical practices in formals education. This can be reflected through the development of formative assessment through peer interaction as a key component of pedagogy (Webb, 2010). 
Autonomy can be scrutinized in terms of; knowledge, skills and attitudes, hence acting as another competence required to develop a truthful and trusted education system. Littlewood (1996) notes that ability can be divided into knowledge and skills. Where knowledge would include an awareness of alternatives that might be chosen, and the necessary skills to implement depending on the choices made. The attitudinal component of autonomy is discussed by Littlewood (1996) under the heading of willingness. He points out that it is not enough to know how to do something, but there must be motivation and confidence to do something (Littlewood, 1996). On the side of the learners or students, Little (1990) gives suggestions on how components of autonomy can be recognised in one's behaviour.

Besides decision making, Little (1990) mentions that there should also be capacity for detachment, critical reflection and independent actions of an individual or institution. Thus, suggesting that autonomy should undeniably be given to schools to determine the rating of their students, such that they resurrect the competence of students and, furthermore, the competence of a country's human resource.

Teachers yawning for autonomy are not in a dreaming mode, but it's the reality since they are the ones who educate their learners. This means that policy makers and the community in general should always be awake to every educational reforms and issues and voices that arise to rectify and provide remedies to national issues and in this case, education and schooling. With such attitudes, a country should expect a bright future for its education system and the general national development.

\section{Outcome:}

This is the knowledge, experience, skills and new attitudes adopted by the learners after learning. It is important for a teacher to know where the student's to finish and what the teacher wants them to learn or to be evaluated on at the end. In this way it is the teacher who knows when the students have got to reach the end, or to achieve the expected objectives. These learning outcomes can be stated as aims and objectives (Reece and Walker, 2000).

\section{Testing/ Assessment:}

Though the terminologies 'testing' and 'assessment' are in most cases used interchangeably, they do not mean the same. 'Assessment' is defined as “a wide range of methods for evaluating learner(s) performance and attainment" (Gipps, 1994). While it evidently generates information about the entire teaching-learning process of a learning activity or program, it is mostly aimed at improving student learning.

\section{CONCLUSION/RECOMENDATION}

To develop a teacher autonomy in regard to students' testing and or assessment perhaps we need to understand the pressure that exist in publicly funded organisations that may act as barriers to encouraging teachers to develop themselves. Government should set governing policies and regulations in this rapidly changing universe where fixed building buildings are soon becoming obsolete and the virtue community is becoming the order of the day.

\section{REFERENCES}

Ali, S and Rizvi, M. (Ed.). (2007). Quality in education: Teaching and leadership in challenging times. Vol. 2. Karachi: Aga Khan University, Institute for Educational Development. Retrieved from http://ecommons.aku.edu/books/7.

Brown, A. (2018). The Advantages of Using Chalkboards in Teaching. Retrieved from https://www.theclassroom.com/advantagesusing-chalkboards-teaching-5872788.html.

Cody, A. (2011). Obama Blasts His Own Education Policies, Living in Dialogue. Retrieved from https://blogs.edweek.org/teachers/living-in dialogue/2011/03/obamas_radical_critique_of_te s.html.

Eurydice. (2008). Levels of Autonomy and Responsibilities of Teachers in Europe. Belgium: Eurydice, European Unit, Avenue Louise 240.

Gipps, C. (1994). Beyond Testing: towards a Theory of Educational Assessment(London, Falmer Press).

Hanushek, A.E and Wößmann, L. (2007). Education Quality and Economic Growth. THE WORLD BANK: Washington, DC. Retrieved from https://siteresources.worldbank.org/EDUCATIO N/Resources/278200-1099079877269/5476641099079934475/Edu_Quality_Economic_Growt h.pdf. 


\section{Wamaungo Juma Abdu. /Journal of Educational Administration Research and Review / Vol.3 No.1 June 2019}

Harker, A. O. D. (1911). The Use of Mandamus to Compel Educational Institutions to Confer Degrees, The Yale Law Journal, Vol. 20, No. 5 (Mar., 1911), pp. 341-352.

Little, D. (2007a). Learner autonomy. Dublin, Authentik.

Little, W. J. (1990b). The Persistence of Privacy; Autonomy and Initiative in Teachers Professional Relations, Teachers College Record, Volume 91, Number 4, Summer 1990.

Littlewood, W. (1996). Autonomy: An autonomy and framework. System, 24(4), 427-435.

McClain, L., Gulbis, A and Hays, D. (2017). Honesty on student evaluations of teaching: effectiveness, purpose, and timing matter! Assessment \& Evaluation in Higher Education, 43(3), 369-385. doi:10.1080/02602938.2017.1350828.

NCTE. (2009). National Curriculum Framework for Teacher Education: Towards Preparing Professional and Humane Teacher. Retrieved from https://www.ncte.gov.in/Website/PDF/NCFTE_2 010.pdf.

OECD. (2013). Synergies for Better Learning: An International Perspective on Evaluation and Assessment. Retrieved from http://www.oecd.org/education/school/synergiesfor-better-learning.htm.

OECD. (2009). Teacher Evaluation: A Conceptual Framework and examples of Country Practices. Mexico, International Practices, Criteria and Mechanisms, held in Mexico City on 1-2 December 2009.

OECD/CERI. (2008). Assessment for Learning Formative Assessment: OECD/CERI International Conference "Learning in the 21st Century: Research, Innovation and Policy".
Retrieved https://www.oecd.org/site/educeri21st/40600533. pdf.

Osmankovic, J., Jahic, H and Sehic, E. (2011). Education in economic theory. Econ Rev-J Econ Bus 9(1):63-79

Ozturk, I. (2001). The Role of Education in Economic Development: A Theoretical Perspective, Journal of Rural Development and Administration, Volume XXXIII, No. 1, Winter 2001, pp. 39-47.

Price, M. E and Verhulst, S. (2000). The concept of selfregulation and the internet. In J. Waltermann \&
M. Machill (Eds.), Protecting our children on the internet: Towards a new culture of responsibility(pp. 133-198). Bertelsmann Foundation Publishers. Retrieved fromhttp://repository.upenn.edu/asc_papers/142.

Rand Education Research Brief. (2004)."The Promise and Peril of Using Value-Added Modeling to Measure Teacher Effectiveness." Santa Monica, Ca.: Rand Education.

Reece, I. and Walker, S. (2000). Teaching, training and learning a practical guide. 4th Edition, Business Education Publishers Limited, Sunderland.

Sehrawat, J. (2014). Teacher Autonomy: Key to Teaching success, HARTIYAM INTERNATIONAL JOURNAL OF EDUCATION \& RESEARCHA: quarterly peer reviewed International Journal of Research\& Education, Volume4, Issue 1, December 2014, ISSN:2277-1255.

Sinclair, J. (1995). Collins COBUILD English dictionary, COBUILD series. London: Harper Collins.

Strong, E.G.L. (2012). A Psychometric Study of the Teacher Work-Autonomy Scale with a Sample of U.S. Teachers. Dissertations Presented to Lehigh University.

The White House. (2012). K-12 Education. Retrieved from https://obamawhitehouse.archives.gov/issues/edu cation/k-12.

Wamaungo, J.A. (2014). Education and microfinance as a combined empowerment approach for the microfinance clients: A multiple cases study of two local microfinance organisations in Bandung in Indonesia, submitted to the school of postgraduate studies, January 15, 2015

Webb, M. (2010). Beginning teacher education and collaborative formative e-assessment. Assessment \& Evaluation in Higher Education, 35(5), 597-618. doi:10.1080/02602931003782541.

William, P and Ochan, KP. (2011). How to Teach Now: Five Keys to Personalized Learning in the Global Classroom. Retrieved from http://www.ascd.org 